O. Tymochko ${ }^{1}$, A. Trystan ${ }^{1}$, O. Chernavina ${ }^{2}$, A. Berezhnyi ${ }^{1}$

${ }^{1}$ Ivan Kozhedub Kharkiv National Air Force University, Kharkiv

${ }^{2}$ National Academy of the National Guard of Ukraine, Kharkiv

\title{
THE METHOD OF PLANNING THE FLIGHT ROUTE OF UNMANNED AERIAL VEHICLES WHILE MONITORING THE BEHAVIOR OF DYNAMIC OBJECTS IN THE FOREST-STEPPE AREA
}

The flight route planning method for an unmanned aerial vehicle (UAV) to search for a dynamic object in a forest-steppe area was developed. Indicators and criteria of search efficiency with the participation of UAV were proposed. They allow you to choose the route that most fully meets the goals and objectives of the search. A numerical estimates of the search efficiency indicator were obtained for choosing a rational UAV flight route under conditions of uncertain behavior of a dynamic object.

Keywords: Unmanned aerial vehicle, route planning, search for dynamic objects, search operation, foreststeppe area.

\section{Introduction}

Formulation of the problem. The rapid development of unmanned aircraft in recent years has changed the organization of monitoring stationary and dynamic objects. This is due to the following: unmanned aerial vehicles (UAV) are much cheaper than manned reconnaissance aircraft; UAVs are easier to maintain and manage; UAVs can operate at night, in conditions of poor visibility, in situations that threaten the life of the pilot. The tasks of finding dynamic objects on the ground are not new. However, there are features for the forest-steppe zone. It contains significant areas of forest. The search for objects of observation in such areas is complicated. The process of selecting the optimal flight routes is particular difficulty. In this case, it is not only about completing purely civilian missions, but also about solving military tasks [1].

Recently, the forms and methods of armed struggle are being transformed (Syria, Iraq, Libya, East Ukraine). The combat use of highly mobile, small groups, that can carry out terrorist tasks, comes to the fore. Modern terrorism is a complex socio-political phenomenon as a form of political struggle, as a form of behavior of individuals and organized groups. They, disrupting public order, destabilize the process of public life, contribute to the creation and development of conflict situations. Reliable and timely information is needed to counter the terrorist attacks of such groups. It can be quickly obtained by conducting active reconnaissance (monitoring).

Let the monitoring target a specific terrorist group (TG). It is necessary to predict the possible actions of this group. The forecast will allow an adequate response to emerging threats. TG can operate in areas (areas) of significant size, use the tactical properties of the terrain, especially camouflage and protective. The number of groups and objects of influence can grow. At the same time, uncertainty about the choice of objects of influence is growing. As a result, it is necessary to simultaneously monitor large areas quickly.

In the face of uncertain information about the possible actions of TG, existing methods of conducting air reconnaissance using UAV are becoming ineffective. The probabilistic estimates of obtaining positive TG exploration results using existing methods are close to zero. The existing methods for substantiating the routes and methods of conducting TG aerial reconnaissance using UAV in the forest-steppe area do not correspond to the methods for predicting their actions. Therefore, given the uncertainty of TG actions, UAV aerial reconnaissance may not ensure their timely detection and recognition.

Planning aerial reconnaissance route using UAV in the forest-steppe area requires the identification and consideration of special patterns in TG actions. The intelligence plan itself should provide for advancing the enemy in action.

A forecast of possible TG actions will give a result if information on their initial location (time, coordinates, state) is known. In this case, the results of aerial reconnaissance using UAV will provide information on the direction of movement, a possible target, the time TG leaves the target. This information will allow for the timely preparation of measures to counter possible terrorist attacks.

To eliminate this discrepancy, the article proposes a method for planning the route of conducting air reconnaissance of the movement and deployment of a terrorist group using unmanned aerial vehicles in the forest-steppe area. A numerical assessment of the intelligence performance indicator is obtained to select one rational of the many options for possible UAV recon- 
naissance flight routes in the face of uncertainty in the actions of a terrorist groups.

Analysis of recent research and publication. An analysis of domestic and foreign literary sources led to the conclusion that the tasks of managing and planning the application of UAV are conditionally divided into three groups. Firstly, it is the automatic recognition of objects in images obtained with UAV, and their processing. Secondly, the management of teams of devices using intelligent information technology. Thirdly, the study of the laws governing the search for stationary and dynamic objects.

In [2], the adaptive background subtraction method is used to automatically detect dynamic objects in images.

In [3], information technology was proposed and developed for the organization of coordinated actions of UAV in the search for land-based mobile objects, which is based on an analysis of the situation. The methods of mathematical modeling, probability theory, mathematical statistics, computer vision are used in article.

In [4], a new UAV motion model was proposed under the name DMM (dynamic motion model). A model of a digital multimeter is proposed, which provides effective search windows. They are based on calculating the maximum pixel intensity for segmenting only specific areas for moving a dynamic object. However, the model does not provide a search in the entire frame area using the SUED method (segmentation using edge dilatation).

In [5], a report is presented on the results of a study conducted from evaluating the performance of AR.Drone for computer vision.

In [6], the problem of efficient image processing with higher resolution using CNN for intelligent UAV in real-time program for cameras was solved.

In [7], the problem of expanding the probabilistic search framework to take into account the properties of flexible UAV was considered. It becomes the basic work for the development of this method.

In [8], the coordination of a group of unmanned aerial vehicles that are deployed to search for a dynamic target in continuous space using the maximum sum algorithm is considered.

In [9], an approach to the distribution of UAV tasks that take part in the search and action mission is presented. Three algorithms for the collective search for a heterogeneous UAV team on a spatially expanded battlefield are described.

The article [10] considers an algorithm for detecting and tracking mobile vehicles with UAV using background scene processing and Kalman filtering.

The results of [11] are important. It describes how to implement a decentralized decision-making structure with multiple agents to solve a time-limited search problem.

In [12], a unified structure was introduced to describe the routing and optimization of the UAV trajecto- ry. However, this article provides only general statements and formalization of the routing problem and an overview of existing methods.

The work [13] is devoted to the development of new and improvement of existing algorithms and application methods of the UAV group, which are engaged in collecting information about a given territory and dynamically changing operational environment. A modified sequential selection algorithm is proposed. The modified version is characterized by minimizing the passage through the reference points of two or more different types of UAV.

Three different strategies for searching for objects were proposed in [14]: random search, track-based search, and network-based search. An analysis of their effectiveness using Monte Carlo simulation is carried out.

The problem of optimal routing for unmanned aerial vehicles is considering in the article [15]. A mathematical model for solving a specific problem and an experiment that is used to test the functionality of the model are presented. The model is developed using mathematical programming methods.

The article [16] discusses the problem of developing objective functions for autonomous search and tracking the observation targets of unmanned aerial vehicles.

In [17], a new approach to the planning of routes for general search and tracking missions by coordinated unmanned aerial vehicles was presented.

In [18], an improved hierarchical probabilistic algorithm for finding targets based on the cooperation of UAV at different heights was proposed. In particular, a method for reducing search time and search distances by improving the transmission of information between high-altitude and low-altitude UAVs is proposed.

In [19], a new basis for UAV search operations was introduced and a new approach to solving the problem of general search for objects by unmanned aerial vehicles was proposed.

The method of planning UAV flight routes in order to search (confirm the status) of stationary objects, taking into account the limitations of the technical capabilities of unmanned aerial vehicles, is considered in article [21].

In article [22-23] proposes a method for planning the flight route of an unmanned aerial vehicle to search for a dynamic object.

The problem of finding rational reconnaissance routes are partially discussed in the article [24].

In article [25] in order to reduce the uncertainty of the movement of a dynamic object, when preparing proposals for solutions for conducting aerial reconnaissance, it is proposed to form time schedules using methods of the theory of probability.

From the results of the brief review, it follows that the tasks of planning the use of UAV to search for dy- 
namic objects in the conditions of forest-steppe terrain with significant disparate wooded areas suitable for masking and constructing the optimal route of movement have not been considered. The base for the development of the corresponding method was the work [3; 7; 9; 12; 14-15; 23-25].

The aim of the article development of a planning method for the use of unmanned aerial vehicles for searching dynamic objects (terrorist groups) in a foreststeppe area.

\section{Statement of basic materials}

\section{Justification of the structure of the method of forming a plan for conducting aerial reconnaissance of dynamic objects using UAV in the forest-steppe area}

TGs can carry out their tasks in a large area where there are several dozen possible targets. In this case, there may not be enough strength or time to organize ground reconnaissance on all possible TG traffic routes.

Aerial reconnaissance with $\mathrm{UAV}$ is required to search for and recognize TGs. They are able to complete the task in a large area in a short time.

The existing UAV aerial reconnaissance plan development scheme needs to be changed. This is because the flight route of the UAV reconnaissance must take into account the TG counteraction, the proposed methods of counteracting the reconnaissance for covert access to targets using forested areas for masking. In the proposed scheme for developing an air reconnaissance plan using UAV, the main role belongs to the route formation procedure.

The proposed AR management plan formation scheme is distinguished by taking into account the many TG movement routes and the many UAV reconnaissance flight routes. Hence the solution to the problem of optimizing options using criteria for the effectiveness of TG actions and air reconnaissance using UAV.

Initially, it is necessary to evaluate the feasibility of conducting TG exploration using UAV. For this, the time of initial detection of TG, their initial location area, is taken into account. If we add the current time with the estimated time TG exit to possible targets, then the first indicator found is the time UAV is ready for aerial reconnaissance $\left(t_{\text {readAR }}\right)$.

The second aerial reconnaissance performance indicator characterizes the responsiveness of aerial reconnaissance missions $\left(t_{\text {implaR }}\right)$. The difference in the values of the two calculated indicators allows us to estimate the necessary time margin $\Delta$ for the organization of counteraction by special forces of the anti-terrorist center.

If $\Delta$ is insufficient, the task of aerial reconnaissance using UAV is impossible, which requires a change in the type of reconnaissance.

Under positive external aerial UAV reconnais- sance conditions prepares baseline data on the assessment of TG actions, which includes the assessment of:

- the numbers of TG;

- numbers of TG areas;

- total area of the intelligence area;

- the numbers of possible impact objects and their characteristics;

- source time and location of TG detection;

- the number and characteristics of natural landscape massifs with camouflage properties (camouflage areas (MA), open areas (OA)) on possible routes of movement TG;

- terrain characteristics on possible routes of movement TG.

After entering the initial data and constructing options for possible TG exit routes to the targets, the number of routes is optimized to the minimum value of the vulnerability index of TG groups on each route.

As a result, one rational route is determined for each object of influence. It has forests with camouflage properties and open areas that TG cannot pass. Using the TG motion model, it is possible to obtain the predicted value of the TG exit time to the middle of each open section for all selected routes to each target.

Thus, from the entire set of open areas, those are distinguished in which with a certain probability the appearance of TG is possible.

Now, the development of an aerial reconnaissance plan is narrowing down to the task of flying around UAV of selected open sections of TG traffic routes precisely at the time that is obtained when solving the probabilistic task of estimating the time TG leaves these sections.

Using the UAV flight model and the UAV-assisted air reconnaissance performance evaluation method (presented below), we optimize the number of all possible flight routes according to the selected efficiency criterion. The substantiation of support and management issues allows you to complete the formation of the plan, make a decision on UAV aerial reconnaissance and set the task.

The scheme for developing a UAV aerial reconnaissance plan is the basis for constructing a method for substantiating a rational TG reconnaissance route using UAV in a forest-steppe area.

\section{TG aerial reconnaissance performance indicators and criteria using UAV in the forest-steppe area}

The basis of the method is the principle of rationality of actions of two opposite sides. When choosing driving routes, they strive to achieve opposite goals. TG seeks to reduce the probability of their detection on the route to objects, and the intelligence side seeks to increase this probability.

Therefore, indicators and criteria for aerial reconnaissance using UAV are divided into two groups. The 
first of them determines the effectiveness of the execution of tasks by the adversary (TG), and the second - the effectiveness of the UAV task.

All $J_{k}$ routes for every $k$-th $(k=1,2, . ., K)$ the impact object are considered. All open areas $i_{k}=1,2, . ., I_{k}$, on each $j_{k}$-th route of movement of TG in the direction of the $k$-th impact object are determined. on which Air reconnaissance of a dynamic object using UAV is possible on each open area.

In this case, the route efficiency indicator is introduced as the degree of vulnerability of TG groups on the route of movement $\left(U_{j k}\right)$ [20]:

$$
U_{j k}=\sum_{i=1}^{I_{k}} r_{i j k} \times \frac{T_{\text {part_ijk }}}{\Delta t_{\text {min }}},
$$

where $T_{\text {part_ijk }}$ - an estimate of the duration of observation of a site when it is overcome by an object of movement ( $i$-th site on the $j$-th route to the $k$-th target);

$\Delta t_{\min }$ - estimation of the minimum required observation time for identification of an object from the air;

$r_{i j k}$ - coefficient equal to one, if the site is included in the analysis of possible reconnaissance, and zero otherwise.

If there are sections on the routes with non-zero vulnerability TG (1), then it is possible to rank routes according to the degree of vulnerability (degree of intelligence TGs).

It is assumed that TG seeks to select the route with the least accumulated degree of vulnerability.

It is advisable to accept the criterion for choosing the rational route of movement TG to accept the condition of not exceeding the value by an indicator $U_{j k}$ of some predetermined limit value $\left(U_{l i t}\right)$ :

$$
U_{j k} \leq U_{\text {lit }}
$$

For all sections of the studied route (for camouflage areas and open areas), the mathematical expectation of time (ME) to overcome them by TG $\left(m_{t_{i j k}}\right)$ and the variance of this random variable $\left(D_{t_{i j k}}\right)$ are calculated.

Let the random variable - the selected speed TG in the elementary section $[a, b]$ - be distributed according to the uniform law

$$
f\left(V_{M A(O A)}\right)= \begin{cases}0, & \text { if } V_{M A(O A)} \notin[a, b] ; \\ \frac{1}{b-a}, & \text { if } V_{M A(O A)} \in[a, b] .\end{cases}
$$

Then the mathematical expectation of the velocity $\left(m_{V}\right)$ with dispersion $\left(D_{V}\right)$ and standard deviation (SD) $\left(\sigma_{V}\right)$ is defined as

$$
m_{V}=\frac{a+b}{2}, D_{V}=\frac{(b-a)^{2}}{12}, \sigma_{V}=\frac{b-a}{2 \sqrt{3}} \text {. }
$$

By appropriate conversion

$$
\begin{aligned}
& g(t)=f(\psi(t)) \cdot\left|\psi^{\prime}(t)\right|=f\left(V_{M A(O A)}(t)\right) \times \\
& \times f\left(V_{M A(O A)}(t)\right)^{\prime}=\frac{1}{b-a} \cdot \frac{L_{M A(O A)}}{t^{2}}
\end{aligned}
$$

you can get the distribution law of a random variable the time of exit from the camouflage area (from an open area).

Then, using the well-known formulas of the distribution function of the random variable $g(t)$, we can obtain the mathematical expectation of the movement time over the section $\left(m_{t}\right)$ :

$$
m_{t}=\int_{L / b}^{L / a} t \cdot g(t) d t=\frac{L}{b-a} \cdot \ln \left(\frac{b}{a}\right),
$$

and variance $\left(D_{t}\right)$ of this random variable

$$
\begin{aligned}
& D_{t}=\int_{L / b}^{L / a}\left(t-m_{t}\right)^{2} \cdot \frac{L}{t^{2}(b-a)} d t= \\
& =\int_{L / b}^{L / a}\left(t-\frac{L}{b-a} \cdot \ln \left(\frac{b}{a}\right)\right)^{2} \cdot \frac{L}{t^{2}(b-a)} d t= \\
& =\frac{L^{2}}{a \cdot b}-\frac{L^{2}}{(b-a)^{2}} \cdot \ln \left(\frac{b}{a}\right)^{2}, \\
& \text { at } b>a, \quad L=L_{M A(O A)} .
\end{aligned}
$$

Using the property of mathematical expectation and variance of the sum of independent random variables, we can calculate the mathematical expectation and variance of the time TG exits to the $k$-th object on the $j_{\kappa}$ -th route:

$$
m_{t_{n j k}}=\sum_{i=1}^{n} m_{t_{i j k}} ; D_{t_{n j k}}=\sum_{i=1}^{n} D_{t_{i j k}} ; n=1,2, . ., N .
$$

From all $J_{k}$ routes of TG exit to the $k$-th object, one should be selected that would better meet the criterion assessment requirement (2).

In total, $K$ routes will be selected (by the number of objects). Of these, using formula (9), we find the total number $R$ of open areas of the terrain over which aerial reconnaissance with UAV is necessary:

$$
R=\sum_{i=1}^{I_{k}} r_{i j k} \text {. }
$$

UAV should fly above each of these open areas while the TG groups are on it.

If we consider each $s$-th $(s=1,2, \ldots, S)$ possible UAV flight route of open sites, then each UAV site flight event will give an increase in the intelligence performance indicator for each of them. This increase in efficiency can be denoted as $\Delta P_{k \text {.recon_n }}$, where $n=1,2$, $\ldots, N$ is the number of the object along the route to which the $k$-th section is located.

Then, as an indicator of the effectiveness $\left(E_{s}\right)$ of the UAV flight route, one can use the estimate of the weighted mathematical expectation of the number of 
TG detections on the s-th reconnaissance flight route

$$
E_{S}=\sum_{n=1}^{N}\left(u_{n} \times \sum_{k} \Delta P_{k_{\text {recon_n }}}\right),
$$

where $u_{n}$ is the weight of the importance of the target to which the route of movement TG leads and where the target is located. The weight of importance is subjectively selected on the interval $[0,1]$ according to whether the reconnaissance site belongs to a specific route of movement of TG.

In this case, for many possible routes, the criterion for choosing the best for reconnaissance will be the requirement to maximize the indicator $E_{s}$ :

$$
\max E=\max _{s} E_{S} \text {. }
$$

Thus, the proposed indicators and criteria for evaluating the effectiveness of aerial reconnaissance of terrorist groups using UAV in the forest-steppe area allow us to obtain the dependence of their estimates on the quality indicators of the selected TG traffic routes. This provides a comparative assessment of the effectiveness, justification and selection of a rational route for conducting air reconnaissance of dynamic objects using UAV.

\section{Methods and algorithms for substantiating the choice of a rational aerial reconnaissance route using UAV with automated assessment of its effectiveness}

\subsection{Automated evaluation of the options for the movement of TG when performing the task}

Automation of the assessment processes is necessary to find a rational version of the TG's actions, to justify the air reconnaissance plan using UAV and to make a search decision. In this case, the algorithms are based on well-known mathematical methods of the theory of operations research and graph theory.

In the general case, the problem is reduced to the description of the structure of the TG action plan for the choice of movement routes to the objects of influence by the methods of graph theory.

Let there be $I$ forested areas (camouflage areas in which a dynamic object cannot be detected) in the search area. Each section has geometric dimensions, within which the length of the route of movement $L_{M A i}$, where $i \in \overline{1, I}$. There are also $J$ open areas between wooded areas. Each of the open sections has geometric dimensions, within which the length of the route of movement along it $L_{O A j}$ is selected, where $j \in \overline{1, J}$.

$N$ possible objects of influence from TG were determined in the search area. The probability of finding TG in the $i$-th camouflage area (CA) (masking area (MA)) is equal $p_{i}^{M A}$. The probability that TG acts on the $n$-th object is equal $p_{n}^{O I}, n=\overline{1, N}$.
We take the set of masking areas $S(M A)$ for the tops of the oriented graph, which can have both incoming edges and outgoing (tops of the first type).

The tops of the second type are the set objects of influence $M(O)$, which have only incoming edges. The set open areas between the masking areas $L(O A)$ form the edges of the directed graph. The same open area cannot connect several pairs of tops.

At the first stage, an unweighted graph is constructed, the number of tops of which (the power of the set of tops) is determined by the formula

$$
V=I+N \text {. }
$$

The number of edges of the constructed graph (the power of the set of edges) is

$$
B=J+N \text {. }
$$

The second term of formula (13) is obtained from the assumption that there is only one way from the masking area to the object of influence.

The task of determining the weights of the edges of the graph is related to the performance indicators of the actions of TG. One of them is the exit time to the $n$ th object of influence from the $i$-th masking area. Then the weights of the edges of the graph correspond to the distance between the masking areas and the objects of influence. The second indicator is advisable to choose the number of open sections along the route TG. The fewer open areas along the route, the less probability it is to detect TG (in this case, the weights of the edges of the graph are taken equal to 1 ).

Determining the weights of the edges of the graph of the initial situation in the search region allows, using well-known methods for solving problems on graphs, to obtain the set possible options for the action of TG.

The solution to this problem is reduced to finding the minimum path from the original top to all the final ones. In this case, the initial tops correspond to masking areas, and the final ones correspond to objects of influence.

This problem can be solved using the Dijkstra algorithm. Repeating the algorithm iteratively for each initial top (masking area), we can obtain the shortest routes from each masking area to the target, which can be conveniently represented as a matrix $Q$ of the following form:

$$
Q=\begin{array}{l|lll} 
& 1 & \ldots & I \\
\hline 1 & q_{11} & \ldots & q_{1 I} \\
\ldots & \ldots & q_{i n} & \ldots \\
N & q_{1 N} & \ldots & q_{I N}
\end{array},
$$

where $q_{i n}$ is a vector that has the form

$$
q_{\text {in }}=\left\{L_{i n}, T_{i n}, N_{i n}, T_{i n}^{\text {entry }}, T_{i n}^{\text {exit }}\right\},
$$

where $L_{i n}-$ is the distance between the $i$-th masking area and the $n$-th target;

$T_{i n}$ - TG movement time between the $i$-th masking area and the $n$-th target; 


$$
N_{\text {in }}=\left\langle l_{i j}\right\rangle, N_{\text {in }} \subseteq L(\Pi), j \in \overline{1, J} \text { - the set of edg- }
$$

es (open areas) along the route of movement of TG to the object;

$$
T_{i n}^{e n t r y}\left(l_{i j}\right)=\left\langle t_{j}^{e n t r y}\right\rangle \text { - the set of values of the time }
$$

of entry into open areas of TG;

$$
T_{i n}^{\text {exit }}\left(l_{i j}\right)=\left\langle t_{j}^{\text {exit }}\right\rangle \text { - the set of TG exit times from }
$$

open areas.

Matrix (14) is a set of rational routes of movement of TG from the starting point to each possible object of influence. From this matrix, for further calculations, the set of all open sections along TG routes to all objects is taken.

\subsection{Automated preparation of proposals} for selecting the parameters of the UAV TG aerial reconnaissance route

Thus, by selecting, according to criterion (3), a family of rational variants of the routes of movement of TG to the objects of influence, it is possible to compose a set of open areas of the terrain $\left(Q_{T G}\right)$ on which it is necessary to conduct TG reconnaissance.

The UAV aerial reconnaissance planning algorithm is expediently performed in two stages:

a) the construction of the set of possible reconnaissance routes with the flight of all open areas precisely during the presence of TG in open areas;

b) the selection of one of the rational UAV flight routes with the maximum intelligence performance indicator.

The compiled set of open areas of the terrain is described by the graph $G=(Q, E)$, where $Q \subset Q_{T \Gamma}$ is the set of tops of the graph corresponding to the set of possible open areas of the terrain along the driving routes TG, and $E$ is the set of the graph edges that are described by the distance between the sections and the UAV flight time between them.

The minimum and maximum possible UAV flight time from one selected reconnaissance section to the next depends on UAV capabilities

$$
t_{m n}^{\max }=\frac{L_{m n}}{V_{U A V}^{\min }} ; t_{m n}^{\min }=\frac{L_{m n}}{V_{U A V}^{\max }} .
$$

The essence of sorting the matrix is to arrange the matrix elements in rows and columns in the order that matches the increase in the number of rows and columns of the matrix with the growth of the time TG goes to the middle of each section. After this, it can be formally stated that the possible UAV flight options have already been built in the lines.

In this case, an reachability matrix [20] (a plurality) of possible UAV flight routes is formed, which does not yet take into account the conditions for the temporary coordination of "UAV arrival and TG arrival" (Tabl. 1). So, the spatial parameters between the reconnaissance areas (tops of the graph) create different conditions for reconnaissance (UAV is not always located above the area at the exact time when TG is supposed to enter it). Therefore, to assess the degree of coincidence of these events, according to the algorithm, an analysis of all rows and columns of this matrix is carried out (Tabl. 1).

Table 1

The result of sorting the UAV flight route matrix

\begin{tabular}{|l|l|l|l|l|l|l|l|}
\hline & $\mathbf{1}$ & $\mathbf{2}$ & $\ldots$ & $\boldsymbol{n}$ & $\ldots$ & $\boldsymbol{N}$ & $\boldsymbol{\Delta P}_{\text {recon_s }}$ \\
\hline $\mathbf{1}$ & 0 & $\boldsymbol{\Delta P}_{\mathbf{1 2}}$ & $\ldots$ & $\boldsymbol{\Delta P}_{\mathbf{1 n}}$ & $\ldots$ & $\boldsymbol{\Delta P}_{1 N}$ & $\boldsymbol{\Delta P}_{\mathbf{1}}$ \\
\hline $\mathbf{2}$ & $<0$ & 0 & $\ldots$ & $\boldsymbol{\Delta P}_{2 n}$ & $\ldots$ & $\boldsymbol{\Delta P}_{2 N}$ & $\boldsymbol{\Delta P}_{\mathbf{2}}$ \\
\hline$\ldots$ & $<0$ & $<0$ & 0 & $\boldsymbol{\Delta P}_{3 n}$ & $\ldots$ & $\boldsymbol{\Delta P}_{3 N}$ & $\boldsymbol{\Delta P}_{\mathbf{3}}$ \\
\hline $\boldsymbol{n}$ & $<0$ & $<0$ & $<0$ & 0 & $\ldots$ & $\boldsymbol{\Delta P}_{\boldsymbol{n} N}$ & $\boldsymbol{\Delta P}_{\boldsymbol{n}}$ \\
\hline$\ldots$ & $<0$ & $<0$ & $<0$ & $<0$ & 0 & $\ldots$ & $\ldots$ \\
\hline $\boldsymbol{N}$ & $<0$ & $<0$ & $<0$ & $<0$ & $<0$ & 0 & 0 \\
\hline
\end{tabular}

Elements of the matrix is a vector, which includes time parameters

$$
\begin{aligned}
& \Delta t_{(n-1) n}=m_{t_{-} n}-m_{t_{-}(n-1)}>0 ; \\
& \Delta t_{n(n-1)}=m_{t_{-}(n-1)}-m_{t_{-} n}<0 .
\end{aligned}
$$

Some elements of the matrix (the shaded part of the table) have negative values of the difference in the expected time TG to the middle of the sections under consideration (due to the sorting principle), and therefore they are turned off from the analysis.

The second symmetric part of the matrix includes elements with positive parameters that can be used in planning aerial reconnaissance. In this case, several conditions are checked, one of which is advisable to write in the form

$$
t_{m n}^{\min }-\sigma_{t_{-} n} \leq m_{t_{-} n}-m_{t_{-} m} \leq t_{m n}^{\max }+\sigma_{t_{-} m} .
$$

Condition (18) allows us to assess the conformity of UAV capabilities and requirements for the arrival of TG in the middle of the next selected section. As you move away from the first reconnaissance section, condition (18) will be less critical due to the increase in dispersion; therefore, the initial reconnaissance sections are more important for analysis.

If the next section in matrix 1 corresponds to condition (18), then it is included in the UAV flight route and the required flight speed and time are calculated for it so that UAV arrival and TG exit to the middle of the section occur at the same time.

To determine the probability of the simultaneous presence of UAV and TG on the exploration section, it is necessary, using the spatial parameters of the section and the lowest possible UAV speed, first calculate the time of UAV entry into and exit from

$$
t_{\text {enter }_{n}}=m_{t_{n}}-\frac{L_{n}}{2 V_{U A V}^{\min }} ; t_{\text {depart }_{n}}=m_{t_{n}}+\frac{L_{n}}{2 V_{U A V}^{\min }},
$$

where $L_{n}$ is the length of the $n$-th section of the UAV flight for reconnaissance.

Then the probability of detecting TG in this section ( $\Delta P_{\text {recon } \_n}$ ) can be found using tabular values of the probability integral [16-17]: 


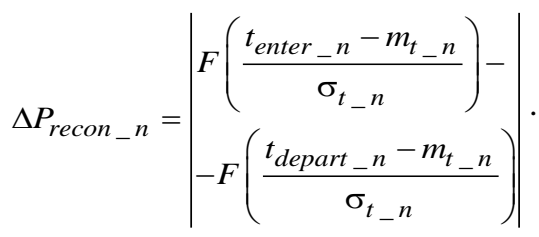

When the end of the matrix row is reached, the formed route is included in the set of possible reconnaissance routes.

Other reconnaissance routes can be formed if exploration is started not from the first, but from subsequent sections. For this, an analysis of the acquisition of the reconnaissance route by sections along other rows of the matrix is carried out (Tabl. 1). The analysis of possible reconnaissance routes ends when the end of the matrix is reached (all rows and columns of the matrix are viewed). This completes the search for all possible routes.

\section{General scheme of the method for justifying the route of conducting aerial reconnaissance of dynamic objects using UAV in the forest-steppe area and evaluating its effectiveness}

The proposed method for substantiating the selection of a rational aerial reconnaissance route involves formalizing decision-making processes, takes into account indicators and criteria for the effectiveness of reconnaissance, and also has its own procedure for obtaining the result (Fig. 1).

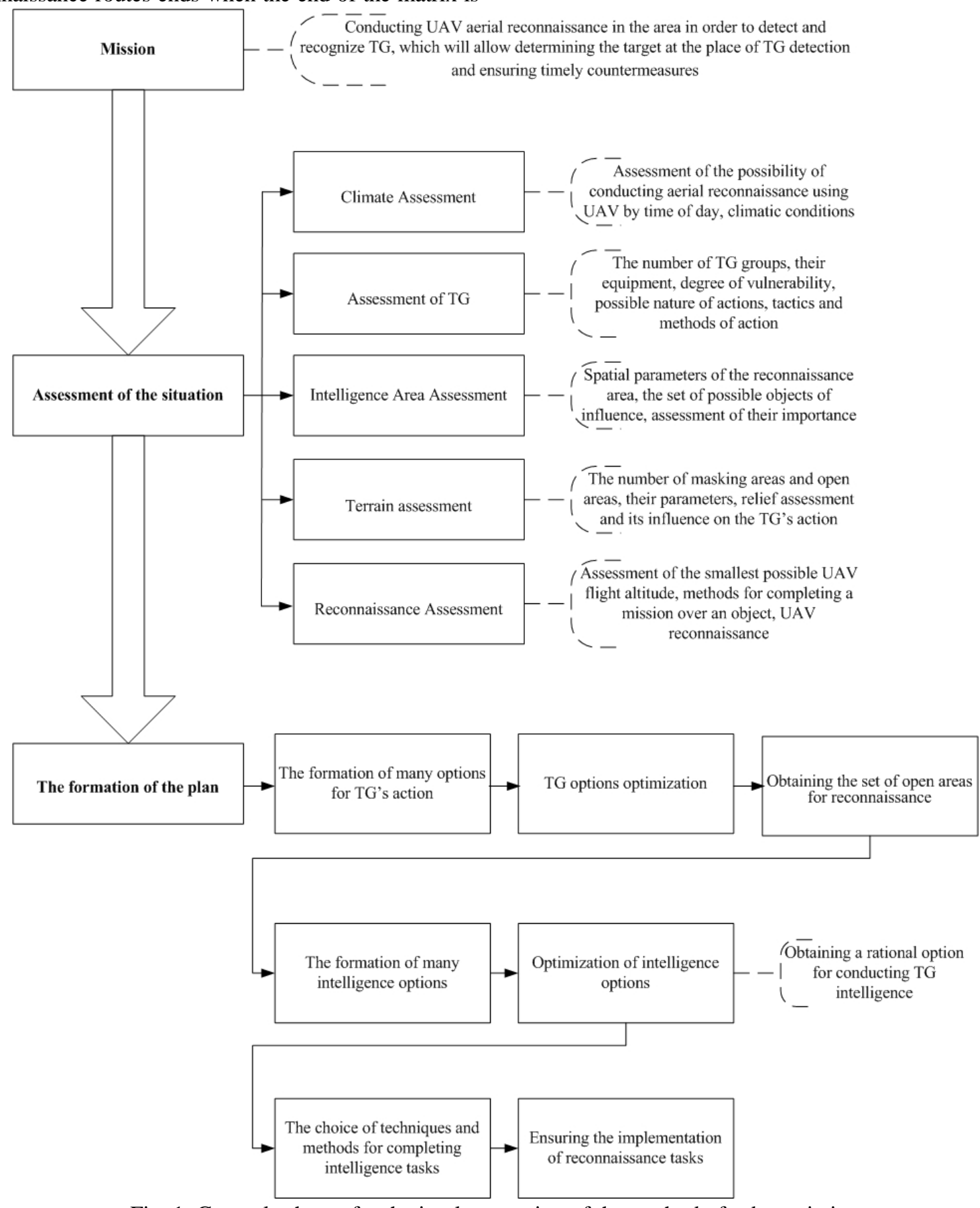

Fig. 1. General scheme for the implementation of the method of substantiation of the rational aerial reconnaissance route UAV TG in the forest-steppe area 
The approach used in the method involves comparing any (final) set of TG reconnaissance options along the routes of their movement and choosing the best one from them. The objective function by which each decision to include in the UAV flight route each open section is evaluated is the probability density distribution of the time TG leaves it in each TG route.

The distribution density functions of a random value of the exit time TG to each of the open sections of one of the specific routes that were considered during the numerical experiment correspond to normal. Since the number of rational routes of movement of TG is determined by the number of objects of influence, the matrix (Tabl. 1) will contain many options for UAV flight routes, the elements of which will be ordered by the time TG leaves for open areas. As you move away from the starting point of movement of TG for the route, the obtained desired probability of detecting TG in the time interval the UAV is above the open section will decrease, which will additionally be affected by the duration of the reconnaissance interval (Fig. 2).

The probability of detecting TG on the entire UAV flight route will allow us to select an option with a high indicator value. The obtained total probability value characterizes the mathematical expectation of the number of TG detections on the entire UAV flight route.

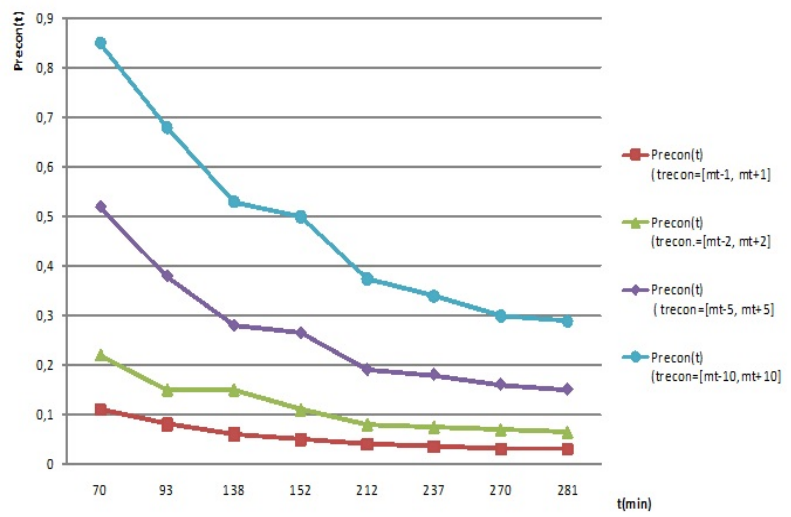

Fig. 2. The results of calculating the probability of reconnaissance of TG on sections of the route as they move away from the starting point to the target and depending on the chosen interval of reconnaissance time (when its average value coincides with the time TG reaches the middle of the section)

The decision-making method for conducting UAV air reconnaissance allows you to select one route option, which will form the basis of the plan.

The existing method of substantiating a rational UAV aerial reconnaissance route for dynamic targets in the forest-steppe area does not have a quantitative assessment of quality. This is explained by the following.

- the principle of "free hunting" is implemented with the task of reconnoitering if an enemy meets;

- reconnaissance of dynamic objects in a forest- steppe area of a certain area does not allow choosing a different performance indicator, except for the ratio of the area on which the object is located to the total reconnaissance area.

Such an approach to evaluation of the effectiveness of the existing method using examples of reconnaissance planning tasks in the forest-steppe area gives a value of the efficiency indicator of about $1 \%$.

The developed method makes it possible to obtain a numerical value of the reconnaissance efficiency in an area of $10000 \mathrm{~km}^{2}$ with 18 possible targets. In this case, the mathematical expectation of the number of TG detections in 56 open sections of a rational UAV flight route can be 31 .

The indicators and the criterion for the effectiveness of TG aerial reconnaissance with UAV defined in the second paragraph of the article make it possible to choose one UAV aerial reconnaissance route from many options. It best meets the goals and objectives of aerial reconnaissance using UAV. Existing UAV aerial reconnaissance planning methods do not take into account the various TG options. Therefore, an reconnaissance plan is formed over the entire area of the district.

The practice of using the developed method according to the simulation results for the forest-steppe area indicates that with its introduction it is possible to a priori evaluate the effectiveness of reconnaissance, as well as increase the efficiency of the process of forming a rational UAV flight route.

\section{Analysis of the results of a numerical experiment on the selection of a rational route for conducting aerial reconnaissance of UAV dynamic objects in the forest-steppe area}

To prove the effectiveness, a numerical experiment was conducted.

For a numerical experiment, forest-steppe terrain was used (Fig. 3).

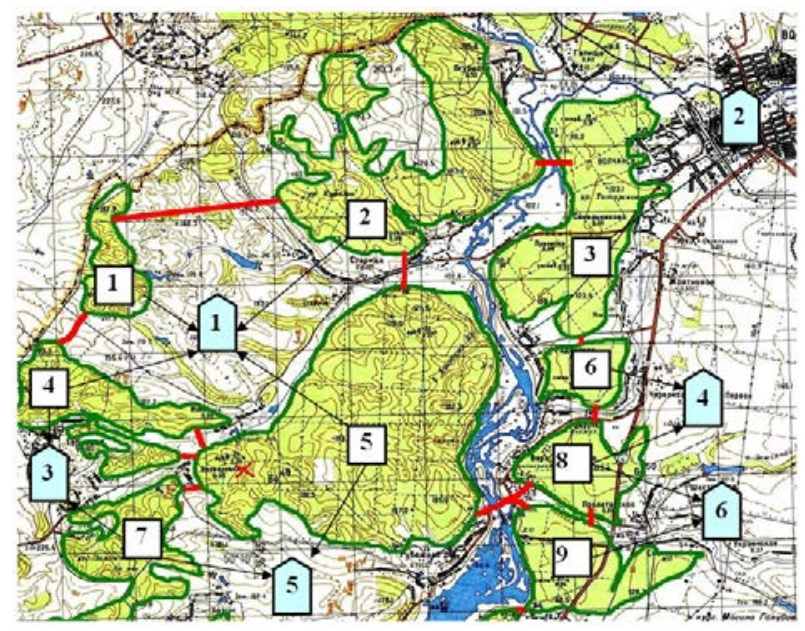

Fig. 3. Map of the search area

As you can see, the initial search area contains nine possible masking areas and six objects of influ- 
ence. To obtain a probability-time estimate of the possible actions of TG, we formalize this map with a graph.

The corresponding graph is shown in Fig. 4, where tops 1-9 correspond to forests (masking areas), and tops 10-15 correspond to objects of influence. We list in Table 2 the characteristics of open areas between masking areas.

Let masking area No. 4 be the source area of the TG base, and object No. 11 as the planned target. Then the probable route of movement TG is defined as the shortest path between the tops No. 4 and No. 11 on the graph (see Fig. 4), which can be found using the Dijkstra algorithm.

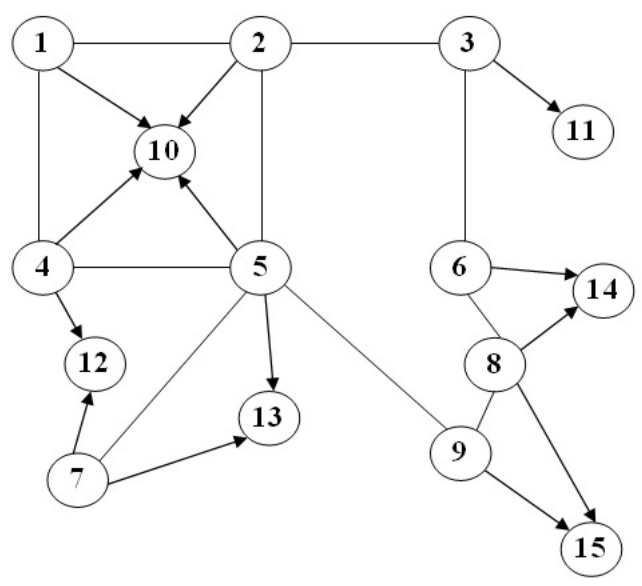

Fig. 4. The graph of the formalization of the search area

The shortest path TG will go through masking areas $5,9,8,6,3$, while the path over open areas will be $7.1 \mathrm{~km}$, based on the data in Table 2. Using specially developed software to simulate the movement of TG on the route, the time is estimated achieve the TG of the selected target.

The calculation showed that for given values of the speed of the group (4-5 km/h), distributed according to the uniform distribution law, the section is divided into 100 segments of $10 \mathrm{~m}$; the number of model runs is 500 . This ensures statistical stability of the results. The mathematical expectation of the passage time of the plot is 0.223 hours, and the standard deviation is $\sigma_{4-5}=0,014$ hours.

Characteristics of open areas in the search area

\begin{tabular}{|c|c|c|c|c|}
\hline $\begin{array}{c}\text { No } \\
\text { i/o }\end{array}$ & $\begin{array}{c}\text { The number } \\
\text { of the open } \\
\text { area (graph } \\
\text { edge) }\end{array}$ & $\begin{array}{c}\text { Length, } \\
{[\mathrm{km}]}\end{array}$ & $\begin{array}{c}\text { Minimum } \\
\text { speed TG, } \\
{[\mathrm{km} / \mathrm{h}]}\end{array}$ & $\begin{array}{c}\text { Maximum } \\
\text { speed TG, } \\
{[\mathrm{km} / \mathrm{h}]}\end{array}$ \\
\hline 1 & 2 & 3 & 4 & 5 \\
\hline 1 & $1-2$ & 10 & 3 & 6 \\
\hline 2 & $1-4$ & 2 & 3 & 6 \\
\hline 3 & $1-10$ & 2 & 3 & 6 \\
\hline 4 & $2-3$ & 1 & 2 & 3 \\
\hline 5 & $2-5$ & 2,5 & 3 & 4 \\
\hline 6 & $2-10$ & 8 & 3 & 5 \\
\hline 7 & $3-6$ & 0,5 & 4 & 5 \\
\hline
\end{tabular}

End of Tabl. 2

\begin{tabular}{|c|c|c|c|c|}
\hline 8 & $3-11$ & 3 & 2 & 3 \\
\hline 9 & $4-5$ & 1 & 4 & 6 \\
\hline 10 & $4-10$ & 3 & 4 & 5 \\
\hline 11 & $4-12$ & 0,6 & 3 & 5 \\
\hline 12 & $5-7$ & 0,7 & 3 & 4 \\
\hline 13 & $5-9$ & 1,2 & 1 & 2 \\
\hline 14 & $5-10$ & 3 & 2 & 6 \\
\hline 15 & $5-13$ & 1,5 & 2 & 5 \\
\hline 16 & $6-8$ & 0,8 & 3 & 5 \\
\hline 17 & $6-14$ & 2 & 2 & 6 \\
\hline 18 & $7-12$ & 1,1 & 2 & 6 \\
\hline 19 & $7-13$ & 3,5 & 2 & 6 \\
\hline 20 & $8-9$ & 0,6 & 3 & 5 \\
\hline 21 & $8-14$ & 1,7 & 2 & 6 \\
\hline 22 & $8-15$ & 2,3 & 2 & 6 \\
\hline 23 & $9-15$ & 0,9 & 2 & 6 \\
\hline
\end{tabular}

The mathematical expectation and standard deviation for each open area along the movement route from the 4-th masking area (4th top of Fig. 4) to the 2-nd exposure object (11th top of Fig. 4) are defined similarly. The results are presented in Tabl. 3 .

Table 3

Prediction of rout time of open sections of TG on a given route

\begin{tabular}{|c|c|c|c|}
\hline $\begin{array}{c}\text { No. } \\
\text { i/o }\end{array}$ & $\begin{array}{c}\text { Edge } \\
\text { number }\end{array}$ & $\begin{array}{c}\text { The mathematical } \\
\text { expectation of rout } \\
\text { time, [h] }\end{array}$ & $\begin{array}{c}\text { Standard } \\
\text { deviation of rout } \\
\text { time, [h] }\end{array}$ \\
\hline 1 & $4-5$ & 0,223 & 0,014 \\
\hline 2 & $5-9$ & 0,8 & 0,075 \\
\hline 3 & $8-9$ & 0,15 & 0,015 \\
\hline 4 & $6-8$ & 0,2 & 0,018 \\
\hline 5 & $3-6$ & 0,11 & 0,006 \\
\hline 6 & $3-11$ & 1,21 & 0,012 \\
\hline
\end{tabular}

Then, the rout time of TG along the masking areas on a given route is determined, based on their characteristics, the results are listed in Tabl. 4. The length of the masking area is taken as the distance from the entrance of the open area to its exit (for this route).

Table 4

Prediction of rout time of TG masking areas on a given route

\begin{tabular}{|c|c|c|c|c|c|c|}
\hline $\begin{array}{l}\text { № } \\
\text { i/o }\end{array}$ & $\begin{array}{l}\text { MA } \\
\text { Number }\end{array}$ & $\begin{array}{l}\text { Length, } \\
{[\mathrm{km}]}\end{array}$ & $\begin{array}{l}\text { Min. } \\
\text { V TG, } \\
{[\mathrm{km} / \mathrm{h}]}\end{array}$ & $\begin{array}{l}\text { Max. } \\
\text { V TG, } \\
{[\mathrm{km} / \mathrm{h}]}\end{array}$ & $\begin{array}{l}\text { ME } \\
\text { rout } \\
\text { time, } \\
{[\mathrm{h}]}\end{array}$ & $\begin{array}{l}\text { SD } \\
\text { rout } \\
\text { time, } \\
{[\mathrm{h}]}\end{array}$ \\
\hline 1 & 4 & 3 & 2 & 3 & 1,21 & 0,02 \\
\hline 1 & 2 & 3 & 4 & 5 & 6 & 7 \\
\hline 2 & 5 & 10 & 2 & 3 & 2,84 & 0,03 \\
\hline 3 & 9 & 1,5 & 3 & 4 & 0,43 & 0,0013 \\
\hline 4 & 8 & 3 & 2 & 3 & 1,21 & 0,02 \\
\hline 5 & 6 & 1,5 & 2 & 3 & 0,6 & 0,012 \\
\hline 6 & 3 & 5 & 2 & 3 & 2,03 & 0,02 \\
\hline
\end{tabular}

Given that the mathematical expectation of the sum of independent random variables distributed according to the normal distribution law is equal to the 
sum of mathematical expectations, and the dispersion of the sum of independent random variables is the sum of dispersions, we write the results of modeling the movement of TG along the route in Tabl. 5.

The timeline of the movement of TG from the 4-th masking area to the 2-nd impact object (the 11-th top of the graph) is shown in Fig. 5. In Fig. 5, the numbers in the circle indicate the number of the route section corresponding to the line in Tabl. 5.

Prediction of the rout time of TG along a route

Table 5

(No.4-No.11)

\begin{tabular}{|c|c|l|c|c|c|c|c|}
\hline $\begin{array}{l}\text { No } \\
\text { i/o }\end{array}$ & $\begin{array}{l}\text { Route } \\
\text { section }\end{array}$ & $\begin{array}{l}\text { ME of } \\
\text { entry } \\
\text { time, } \\
{[\mathrm{h}]}\end{array}$ & $\mathrm{SD},[\mathrm{h}]$ & $\begin{array}{l}3 * \mathrm{SD}, \\
{[\mathrm{h}]}\end{array}$ & $\begin{array}{l}\mathrm{ME} \text { of } \\
\text { exit } \\
\text { time, } \\
{[\mathrm{h}]}\end{array}$ & SD, [h] $]$ & $\begin{array}{l}3 * \mathrm{SD}, \\
{[\mathrm{h}]}\end{array}$ \\
\hline 1 & MA №4 & 0 & 0 & 0 & 1,21 & 0,02 & 0,06 \\
\hline 2 & $\begin{array}{c}\text { OA №4- } \\
5\end{array}$ & 1,21 & 0,02 & 0,06 & 1,433 & 0,024 & 0,084 \\
\hline
\end{tabular}

End of Tabl. 5

\begin{tabular}{|c|c|c|c|c|c|c|c|}
\hline 3 & MA №5 & 1,433 & 0,024 & 0,084 & 4,273 & 0,039 & 0,117 \\
\hline 4 & $\begin{array}{c}\text { OA №5- } \\
9\end{array}$ & 4,273 & 0,039 & 0,117 & 5,073 & 0,085 & 0,255 \\
\hline 5 & MA №9 & 5,073 & 0,085 & 0,255 & 5,503 & 0,085 & 0,255 \\
\hline 6 & $\begin{array}{c}\text { OA №9- } \\
8\end{array}$ & 5,503 & 0,085 & 0,255 & 5,653 & 0,086 & 0,258 \\
\hline 7 & MA №8 & 5,653 & 0,086 & 0,258 & 6,763 & 0,088 & 0,264 \\
\hline 8 & $\begin{array}{c}\text { OA №8- } \\
6\end{array}$ & 6,763 & 0,088 & 0,264 & 6,964 & 0,09 & 0,27 \\
\hline 9 & MA №6 & 6,964 & 0,09 & 0,27 & 7,564 & 0,092 & 0,276 \\
\hline 10 & $\begin{array}{c}\text { OA №6- } \\
\text { 3 }\end{array}$ & 7,564 & 0,092 & 0,276 & 7,674 & 0,1 & 0,3 \\
\hline 11 & MA №3 & 7,674 & 0,1 & 0,3 & 9,704 & 0,11 & 0,33 \\
\hline
\end{tabular}

Similarly, the forecast of the travel time TG along the route was made when it moves from the fourth masking area to the 4-th, 5-th and 6-th impact object (tops 14, 13, 15 of the graph, respectively).

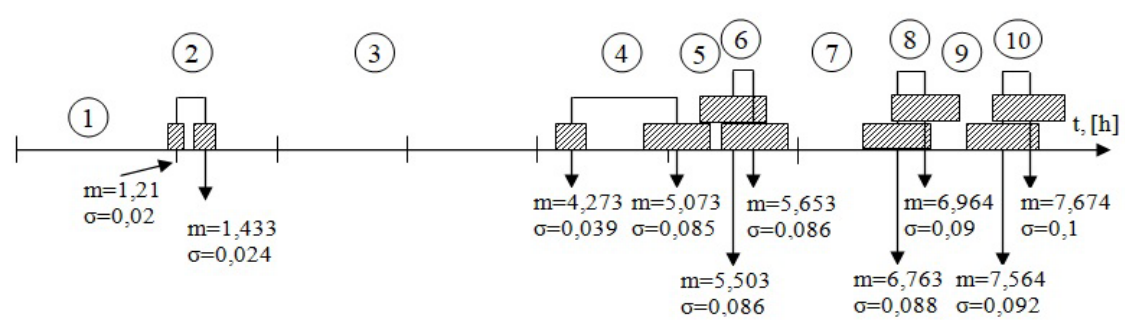

Fig. 5. Timeline of the movement of TG along the route No. 4 - No. 11

Applying Dijkstra's algorithm for an oriented weighted graph (Fig. 4), we obtained TG routes from the 4th masking area to the 4-th, 5-th, and 6-th impact objects, respectively. According to the data from Tabl. 2; 4, Tabl. 6-8 are filled, similar to Tabl. 5 (prediction of the rout time of TG along the route).

Prediction of the rout time of TG along a route (No.4-No.14)

\begin{tabular}{|c|c|c|c|c|c|c|c|}
\hline $\begin{array}{l}\text { № } \\
\text { i/o }\end{array}$ & $\begin{array}{l}\text { Route } \\
\text { section }\end{array}$ & $\begin{array}{l}\text { ME of } \\
\text { entry } \\
\text { time, } \\
{[\mathrm{h}]}\end{array}$ & SD, [h] $]$ & $\begin{array}{l}\text { 3*SD, } \\
{[\mathrm{h}]}\end{array}$ & $\begin{array}{l}\text { ME of exit } \\
\text { time, [h] }\end{array}$ & $\begin{array}{l}\text { SD, } \\
{[\mathrm{h}]}\end{array}$ & $\begin{array}{l}3 * \mathrm{SD}, \\
{[\mathrm{h}]}\end{array}$ \\
\hline 1 & MA №4 & 0 & 0 & 0 & 1,21 & 0,02 & 0,06 \\
\hline 2 & OA №4-5 & 1,21 & 0,02 & 0,06 & 1,433 & 0,024 & 0,084 \\
\hline 3 & MA №5 & 1,433 & 0,024 & 0,084 & 4,273 & 0,039 & 0,117 \\
\hline 4 & OA №5-9 & 4,273 & 0,039 & 0,117 & 5,073 & 0,085 & 0,255 \\
\hline 5 & MA №9 & 5,073 & 0,085 & 0,255 & 5,503 & 0,085 & 0,255 \\
\hline 6 & OA №9-8 & 5,503 & 0,085 & 0,255 & 5,653 & 0,086 & 0,258 \\
\hline 7 & MA №8 & 5,653 & 0,086 & 0,258 & 6,763 & 0,088 & 0,264 \\
\hline 8 & OA №8- & 6,763 & 0,88 & 0,264 & 7,233 & 0,09 & 0,27 \\
\hline
\end{tabular}

Temporary TG graphs for each route are presented in Fig. 6. So, with the initial presence of TG in the 4-th masking area (see Fig. 4), it must be searched for in an open area 4-5. At the same time, the UAV flight time over this section for guaranteed TG presence on it should be $t_{\min }=1,21+0,06=1,27$ hours from the moment the TG was detected to $t_{\max }=1,433+0,084=1,349$ hour - the time the group left the open area. TG is guaranteed to be in an open area for about 5 minutes, which is enough to detect it using UAV.

Table 7

Prediction of the rout time of TG along a route (No.4-No.13)

\begin{tabular}{|l|l|l|c|c|c|c|c|}
\hline $\begin{array}{l}\text { № } \\
\text { i/o }\end{array}$ & $\begin{array}{l}\text { Route } \\
\text { section }\end{array}$ & $\begin{array}{l}\text { ME of } \\
\text { entry } \\
\text { time, } \\
\text { [h] }\end{array}$ & SD, [h] $]$ & $\begin{array}{l}\text { 3*SD, } \\
{[\mathrm{h}]}\end{array}$ & $\begin{array}{l}\text { ME of exit } \\
\text { time, [h] }\end{array}$ & $\begin{array}{l}\text { SD, } \\
{[\mathrm{h}]}\end{array}$ & $\begin{array}{l}3 * \mathrm{SD}, \\
{[\mathrm{h}]}\end{array}$ \\
\hline 1 & MA №4 & 0 & 0 & 0 & 1,21 & 0,02 & 0,06 \\
\hline 2 & $\begin{array}{l}\text { OA №4- } \\
\text { 5 }\end{array}$ & 1,21 & 0,02 & 0,06 & 1,433 & 0,024 & 0,084 \\
\hline 3 & MA №5 & 1,433 & 0,024 & 0,084 & 4,273 & 0,039 & 0,117 \\
\hline 4 & $\begin{array}{l}\text { OA №5- } \\
\text { 13 }\end{array}$ & 4,273 & 0,039 & 0,117 & 4,733 & 0,04 & 0,12 \\
\hline
\end{tabular}

Table 8

Prediction of the rout time of TG along a route (No.4-No.15)

\begin{tabular}{|c|l|c|c|c|c|c|c|}
\hline $\begin{array}{l}\text { № } \\
\text { i/o }\end{array}$ & $\begin{array}{l}\text { Route } \\
\text { section }\end{array}$ & $\begin{array}{l}\text { ME of } \\
\text { entry } \\
\text { time, [h] }\end{array}$ & $\begin{array}{l}\text { SD, } \\
{[\mathrm{h}]}\end{array}$ & $\begin{array}{l}\text { 3*SD, } \\
{[\mathrm{h}]}\end{array}$ & $\begin{array}{l}\text { ME of exit } \\
\text { time, [h] }\end{array}$ & $\begin{array}{l}\mathrm{SD}, \\
{[\mathrm{h}]}\end{array}$ & $\begin{array}{l}3 * \mathrm{SD}, \\
{[\mathrm{h}]}\end{array}$ \\
\hline 1 & MA №4 & 0 & 0 & 0 & 1,21 & 0,02 & 0,06 \\
\hline 2 & $\begin{array}{c}\text { OA } \\
\text { №4-5 }\end{array}$ & 1,21 & 0,02 & 0,06 & 1,433 & 0,024 & 0,084 \\
\hline 3 & MA №5 & 1,433 & 0,024 & 0,084 & 4,273 & 0,039 & 0,117 \\
\hline 4 & $\begin{array}{c}\text { OA } \\
\text { №5-9 }\end{array}$ & 4,273 & 0,039 & 0,117 & 5,073 & 0,085 & 0,255 \\
\hline 5 & MA №9 & 5,073 & 0,085 & 0,255 & 5,503 & 0,085 & 0,255 \\
\hline 6 & $\begin{array}{c}\text { OA } \\
\text { №9-15 }\end{array}$ & 5,503 & 0,085 & 0,255 & 5,723 & 0,086 & 0,258 \\
\hline
\end{tabular}


If it is not possible to conduct UAV aerial reconnaissance in a given open area (for example, due to the untimely receipt of information about the initial location of the TG), UAV aerial reconnaissance in an open area between masking areas 5-9 should be carried out (see Fig. 4), except for the exit option TG to the 5-th target.

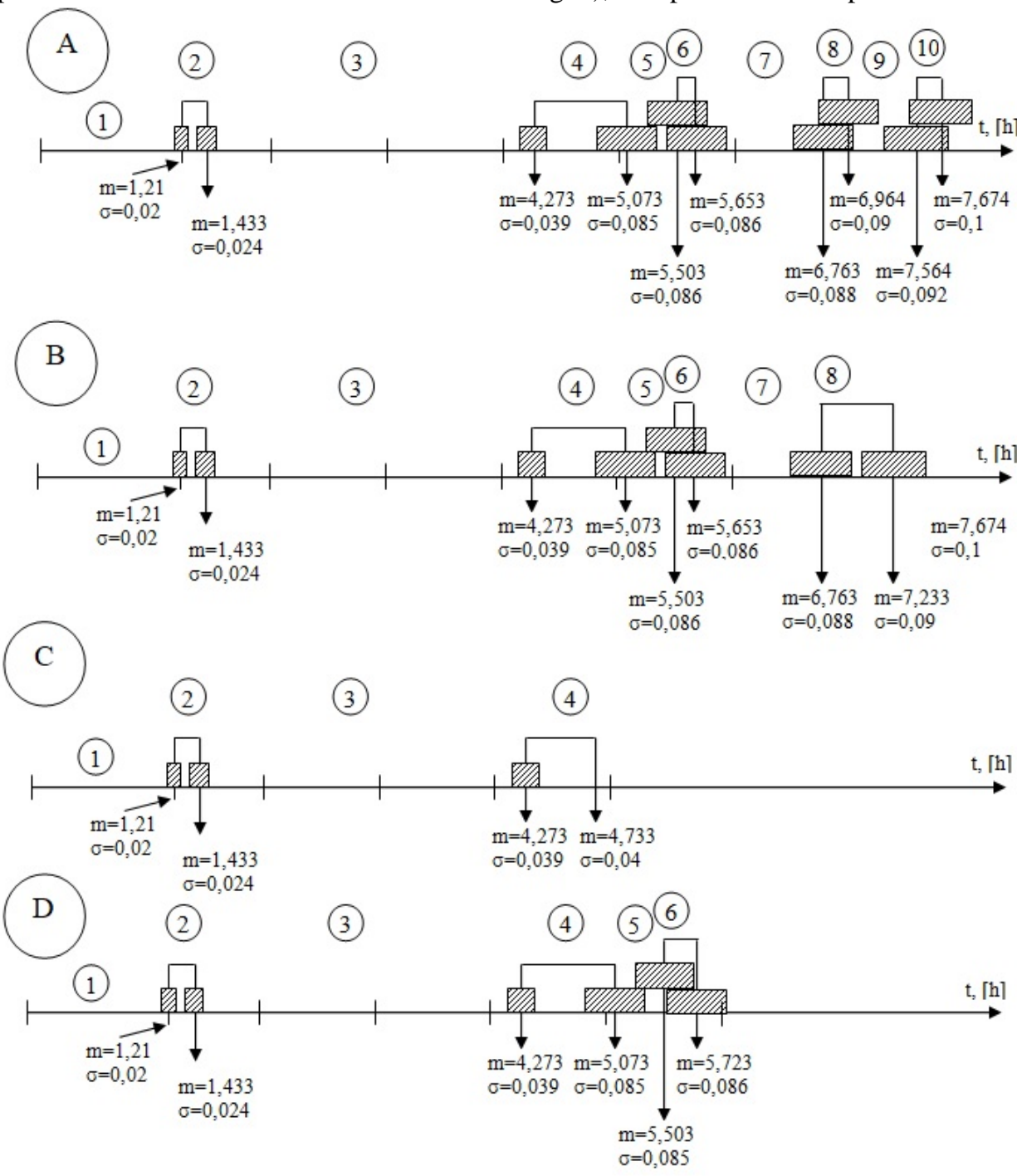

Fig. 6. Timelines of TG movement from the 4th camouflage area

(A - route “4-11”, B - route “4-14”, C - route “4-13”, D - route “4-15”)

The guaranteed time of finding TG in this open area is: $t_{\min }=4,273+0,039 \cdot 3=4,39$ hours from the moment of detection of TG to $t_{\max }=5,073-0,085 \cdot 3=4,818$ hours - the time TG leaves the open area. Thus, the guaranteed time of finding TG in an open area will be approximately 25 minutes, which is sufficient for detecting TG using UAV.

We build the TG timelines for each route. The time spent by TG in the open area between masking areas 9 and 8 (see Fig. 4) is shown in Fig. 6. The possibility of finding TG in this open area is possible only when TG is applied to the impact objects No. 4 and No. 6 (see Fig. 4, the tops columns No. 11 and No. 14 on Fig. 5).

The enter time TG on this open area is a random variable distributed according to the normal distribution law with parameters $m_{\text {entry }}=5,503 ; \sigma_{\text {entry }}=0,086$.

The exit time TG from the open area is a random variable distributed according to the normal distribution law with parameters $m_{\text {exit }}=5,653 ; \sigma_{\text {exit }}=0,086$.

To determine the probability of finding TG in this open area, we define boundary probability intervals based on the "three sigma" rule (Fig. 7).

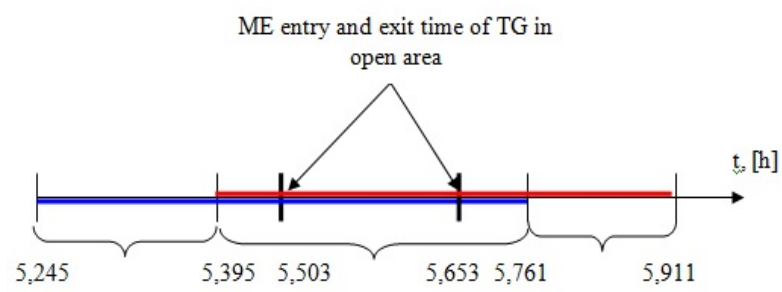

Fig. 7. Timeline of the passage of TG open area 
The blue line shows the dispersion of a random variable - the time TG appeared in this open area, and the red line shows the dispersion of a random value of the time TG leaves the open area.

Knowing that both random variables are distributed according to the normal distribution law, we find the probability of finding TG in each time interval presented on the graph.

First time interval is [5,245; 5,395].

The probability that TG will be in an open area in a given time interval is equal to

$$
P_{1}=F\left(\frac{5,395-5,503}{0,086}\right)-F\left(\frac{5,245-5,503}{0,086}\right) \approx 0,4 .
$$

Second time interval is $[5,395 ; 5,761]$.

The probability of finding TG in an open area in a given time interval consists of the probability of two independent events: the probability $P_{2}^{\text {entry }}$ that TG will be in a given interval, and the probability $P_{2}^{n l}=1-P_{2}^{\text {exit }}$ that TG will not leave this open area. Thus, $P_{2}=P_{2}^{\text {entry }} \cdot\left(1-P_{2}^{\text {exit }}\right)$ :

$$
\begin{gathered}
P_{2}^{\text {entry }}=\Phi\left(\frac{5,761-5,503}{0,086}\right)-\Phi\left(\frac{5,395-5,503}{0,086}\right) \approx 0,6 \\
P_{2}^{\text {exit }}=\Phi\left(\frac{5,761-5,653}{0,086}\right)-\Phi\left(\frac{5,395-5,653}{0,086}\right) \approx 0,6 \\
P_{2}=0,6 \cdot(1-0,6)=0,24 .
\end{gathered}
$$

Third time interval is $[5,761 ; 5,911]$.

The probability that TG will be in an open area in a given time interval is equal to

$$
P_{3}=1-\left[\Phi\left(\frac{5,911-5,653}{0,086}\right)-\Phi\left(\frac{5,761-5,653}{0,086}\right)\right] \approx 0,6 \text {. }
$$

Thus, it is possible to determine the probability of finding TG in an open area in any time range and set the time range for viewing the open area to achieve a probability of finding at least a given one.

We take the probability of the correct recognition of the TG using UAV $-P_{R C}=0,9$, and the probability of the correct identification of the ground object as TG $P_{I D}=0,8$. We accept the equally probable hypothesis about the objects of influence for TG, which are in the 4-th masking area.

Let us determine the probability of completing the UAV aerial reconnaissance task for the considered example.

As previously shown, to complete the UAV aerial reconnaissance mission, plan to fly around open sections according to the following schedule.

The probability that UAV acts from the 4-th MA on the 2-nd impact object (11-th top of the graph in Fig. 4). The probability of fulfilling the UAV aerial reconnaissance task in this case when flying around open areas, according to Tabl. 9, is

\begin{tabular}{|c|c|c|c|c|c|c|c|}
\hline $\begin{array}{l}\text { № } \\
\text { i/o }\end{array}$ & $\begin{array}{l}\text { Open } \\
\text { Area } \\
\text { Number }\end{array}$ & $\begin{array}{l}\text { Entry } \\
\text { time }\end{array}$ & $\begin{array}{l}\text { Depar- } \\
\text { ture } \\
\text { time }\end{array}$ & \begin{tabular}{|lr} 
The & proba- \\
bility & of \\
finding & $\mathrm{TG}$ \\
in an open \\
area
\end{tabular} & $P_{R C}$ & $P_{I D}$ & $P_{A R}$ \\
\hline 1 & $\begin{array}{c}\text { OA №4- } \\
5\end{array}$ & $\begin{array}{c}1 \mathrm{~h} \\
16 \mathrm{~min}\end{array}$ & $\begin{array}{c}\text { 1h } 21 \\
\min \end{array}$ & 1 & 0,9 & 0,8 & 0,72 \\
\hline 2 & $\begin{array}{c}\text { OA №5- } \\
9\end{array}$ & $\begin{array}{c}4 \mathrm{~h} 25 \\
\min \end{array}$ & $\begin{array}{c}4 \mathrm{~h} 50 \\
\min \end{array}$ & 1 & 0,9 & 0,8 & 0,72 \\
\hline 3 & $\begin{array}{c}\text { OA №9- } \\
8\end{array}$ & $\begin{array}{c}5 \text { h } 45 \\
\min \end{array}$ & $\begin{array}{c}5 \mathrm{~h} 54 \\
\min \end{array}$ & 0,6 & 0,9 & 0,8 & 0,432 \\
\hline 4 & $\begin{array}{c}\text { OA № } \\
8-6\end{array}$ & $\begin{array}{c}6 \mathrm{~h} 42 \\
\min \end{array}$ & $\begin{array}{c}7 \mathrm{~h} 02 \\
\min \end{array}$ & 0,52 & 0,9 & 0,8 & 0,37 \\
\hline 5 & $\begin{array}{c}\text { OA № } \\
6-3\end{array}$ & $\begin{array}{c}7 \mathrm{~h} 22 \\
\min \end{array}$ & $\begin{array}{c}7 \mathrm{~h} 31 \\
\min \end{array}$ & 0,6 & 0,9 & 0,8 & 0,432 \\
\hline
\end{tabular}

$$
\begin{aligned}
& P_{A R_{4-2}}=1-(1-0,72) \cdot(1-0,72) \cdot(1-0,432) \times \\
& \times(1-0,37) \cdot(1-0,432)=0,984 .
\end{aligned}
$$

Table 9

Schedule of open area during UAV aerial reconnaissance missions

The probability that TG acts from the 4-th MA on the 4-th object of influence (the 14-th top of the graph in Fig. 4) $P_{4-4}=0,25$. The probability of completing the UAV aerial reconnaissance task in this case when flying around open areas, according to Tabl. 9, is

$$
P_{A R_{4-4}}=1-(1-0,72) \cdot(1-0,72) \cdot(1-0,432)=0,955 .
$$

The probability that TG acts from the 4-th MA on the 5-th object of influence (the 13-th top of the graph in Fig. 4) $P_{4-5}=0,25$. The probability of completing the UAV aerial reconnaissance task in this case when flying around open areas, according to Table 9, is

$$
P_{A R_{4-5}}=1-(1-0,72)=0,72 .
$$

The probability that TG acts from the 4-th MA on the 6-th object of influence (the 15-th top of the graph in Fig. 4) $P_{4-6}=0,25$. The probability of completing the UAV aerial reconnaissance task in this case when flying around open areas, according to Tabl. 9, is

$$
P_{A R_{4-6}}=1-(1-0,72) \cdot(1-0,72)=0,9216 .
$$

Thus, the probability of successful UAV aerial reconnaissance using the proposed approach, provided that the TG is in the 4th masking area (see Fig. 4), is

$$
\begin{aligned}
& P_{A R}=0,25 \cdot 0,984+0,25 \cdot 0,955+0,25 \cdot 0,72+ \\
& +0,25 \cdot 0,9216=0,895 .
\end{aligned}
$$

The effectiveness of aerial reconnaissance when finding TG in other masking areas is similarly calculated.

\section{Conclusions}

Thus, as a result of the research, we can draw the following conclusions:

1. The method of planning an aerial reconnais- 
sance route involving UAV determines the sequence of actions when forming decisions on reconnaissance using developed indicators and criteria, and a method for assessing the effectiveness of aerial reconnaissance with UAV.

2. The method of planning an aerial reconnaissance route with the participation of UAV TG in the forest-steppe area is to reduce the uncertainty of the actions of TG by creating a rational route for conducting aerial reconnaissance UAV on a variety of possible TG routes.
Table 10

Optimization of the traffic routes of TG to the object No. 1

\begin{tabular}{|c|l|l|l|l|l|l|l|l|}
\hline \multirow{2}{*}{$\begin{array}{l}\text { No.OA } \\
\text { No.MA }\end{array}$} & \multicolumn{7}{|l|}{$\begin{array}{l}\text { Increase in the degree of vulnerability of } \\
\text { TG }\left(U_{j k}\right) \text { on traffic routes }\end{array}$} \\
\cline { 2 - 9 } & 1 & 2 & 3 & 4 & 5 & 6 & 7 & \\
\hline \multirow{5}{*}{1} & 12,3 & 8,4 & 0 & 3,35 & 0 & 0 & 3,4 & 28,45 \\
\cline { 2 - 9 } & 12,3 & 0 & 2,34 & 3,35 & 3,2 & 0 & 0 & 21,19 \\
\cline { 2 - 9 } & 0 & 8,4 & 2,34 & 0 & 3,2 & 5,6 & 0 & 19,54 \\
\cline { 2 - 9 } & 0 & 8,4 & 2,34 & 0 & 3,2 & 5,6 & 3,4 & 22,94 \\
\cline { 2 - 8 } & 0 & 8,4 & 0 & 3,35 & 0 & 5,6 & 3,4 & 20,75 \\
\hline
\end{tabular}

Table 11

Optimization of UAV flight routes for searching for TG in open areas of the entire set of routes of their traffic

\begin{tabular}{|c|c|c|c|c|c|c|c|c|c|c|c|c|}
\hline \multirow[t]{2}{*}{ No. OA } & \multicolumn{11}{|c|}{$\begin{array}{l}\text { Increase in the ME number of detections for open areas along the TG traffic routes } \\
\text { (in the general numbering on the map of the search area - Fig. 3, 4) }\end{array}$} & \multirow[t]{2}{*}{$\Sigma \Delta P$} \\
\hline & 4 & 1 & 3 & 5 & 2 & 6 & 8 & 7 & 10 & 11 & 9 & \\
\hline 4 & 0,871 & 0,054 & 0,268 & 0,32 & 0,193 & 0,142 & 0,21 & 0,045 & 0,223 & 0,12 & 0,11 & 6,556 \\
\hline 1 & & 0,768 & 0,311 & 0,42 & 0,522 & 0,543 & 0,136 & 0,33 & 0,256 & 0,23 & 0,21 & 3,726 \\
\hline 3 & & & 0,823 & 0,623 & 0,427 & 0,557 & 0,218 & 0,214 & 0,347 & 0,215 & 0,331 & 3,755 \\
\hline 5 & & & & 0,795 & 0,372 & 0,524 & 0,2 & 0,268 & 0,41 & 0,32 & 0,299 & 3,188 \\
\hline 2 & & & & & 0,828 & 0,569 & 0,432 & 0,325 & 0,338 & 0,278 & 0,311 & 3,081 \\
\hline 6 & & & & & & 0,899 & 0,523 & 0,335 & 0,249 & 0,326 & 0,239 & 2,571 \\
\hline 8 & & & & & & & 0,92 & 0,659 & 0,325 & 0,254 & 0,336 & 2,494 \\
\hline 7 & & & & & & & & 0,879 & 0,461 & 0,433 & 0,335 & 2,108 \\
\hline 10 & & & & & & & & & 0,827 & 0,546 & 0,322 & 1,695 \\
\hline 11 & & & & & & & & & & 0,799 & 0,677 & 1,476 \\
\hline 9 & & & & & & & & & & & 0,924 & 0,924 \\
\hline
\end{tabular}

3. The practical application of the method of planning a rational UAV TG aerial reconnaissance route in natural landscape terrain suggests the need to consider a new way to conduct reconnaissance of moving objects in the forest-steppe area, which uses the TG search strategy on possible traffic routes.

4. Further development of this method consists in expanding the planning of air reconnaissance routes by UAV teams, subject to their group interaction and the exchange of information about discovered objects.

\section{References}

1. Berezhnyi, A.O. (2020), “Metody ta informacijna tekhnologhija avtomatyzovanogho planuvannja marshrutiv poljotiv bezpilotnykh litaljnykh aparativ dlja pidvyshhennja efektyvnosti poshuku ob'jektiv: avtoreferat” [Methods and information technology for automated route planning of unmanned aerial vehicles to increase the efficiency of object searches: abstract], Cherkasy, $20 \mathrm{p}$.

2. Kamate, S. and Yilmazer, N. (2015), Application of object detection and tracking techniques for unmanned aerial vehicles, Procedia Computer Science, Vol. 61, pp. 436-441. https://doi.org/10.1016/j.procs.2015.09.183.

3. Krylov, I.G. (2012), "Razrabotka informatsionnoy tekhnologii organizatsii soglasovannykh deystviy gruppy bespilotnykh letatel'nykh apparatov pri poiske mobil'nykh nazemnykh ob'yektov” [Development of information technology for organizing coordinated actions of a group of unmanned aerial vehicles in the search for mobile ground objects], Moscow, $143 \mathrm{p}$.

4. Saif, A.F.M., Prabuwono, A.S. and Mahayuddin, Z.R. (2014), Moving object detection using dynamic motion modelling from UAV aerial images, The Scientific World Journal, 12 p. http://dx.doi.org/10.1155/2014/890619.

5. Coşkun, M. and Ünal, S. (2016), Implementation of tracking of a moving object based on camshift approach with a UAV, Procedia Technology, No. 22, pp. 556-561. https://doi.org/10.1016/j.protcy.2016.01.116.

6. Plastiras, G., Kyrkou, C. and Theocharides, T. (2018), Efficient convnet-based object detection for unmanned aerial vehicles by selective tile processing, Proceedings of the 12th International Conference on Distributed Smart Cameras, pp. 1-6. https://doi.org/10.1145/3243394.3243692.

7. Waharte, S., Symington, A. and Trigoni, N. (2010), Probabilistic search with agile UAVs, 2010 IEEE International Conference on Robotics and Automation, pp. 2840-2845.

8. Delle Fave, F.M., Xu, Z., Rogers, A. and Jennings, N.R. (2010), Decentralised Coordination of Unmanned Aerial Vehicles for Target Search using the Max-Sum Algorithm, AAMAS 2010 Workshop on Agents in Real Time and Environment, Canada, 10 - 14 May 2010, pp. 35-44 .

9. Jin, Y., Liao, Y., Minai, A.A. and Polycarpou, M.M. (2006), Balancing search and target response in cooperative unmanned aerial vehicle (UAV) teams, IEEE Transactions on Systems, Man, and Cybernetics, Part B (Cybernetics), Vol. 36, No. 3, pp. 571-587. 
10. Lee, M.H. and Yeom, S. (2018), Detection and tracking of multiple moving vehicles with a UAV, International Journal of Fuzzy Logic and Intelligent Systems, Vol. 18, No. 3, pp. 182-189. http://doi.org/10.5391/IJFIS.2018.18.3.182.

11. Miki, T., Popović, M., Gawel, A., Hitz, G. and Siegwart, R. (2018), Multi-agent Time-based Decision-making for the Search and Action Problem, 2018 IEEE International Conference on Robotics and Automation (ICRA), pp. 2365-2372.

12. Coutinho, W.P., Battarra, M. and Fliege, J. (2018), The unmanned aerial vehicle routing and trajectory optimization problem, a taxonomic review, Computers \& Industrial Engineering, No. 120, pp. 116-128.

13. Norseyev, S.A. (2016), “Algoritmy predpoletnogo kvazioptimal'nogo opredeleniya marshrutov gruppy bespilotnykh letatel'nykh apparatov" [Algorithms for pre-flight quasi-optimal determination of routes for a group of unmanned aerial vehicles], Kovrov, $182 \mathrm{p}$.

14. George, J., Sujit, P. . and Sousa, J.B. (2011), Search strategies for multiple UAV search and destroy missions, Journal of Intelligent \& Robotic Systems, Vol. 61, Issue 1-4, pp. 355-367.

15. Teichmann, D., Dorda, M., Vítek, J., Smrž, V. and Michalík, V. (2014), Unmanned aerial vehicles routing problem, Proceedings of the 2014 15th International Carpathian Control Conference (ICCC), pp. 602-607. https://doi.org/10.1109/CarpathianCC.2014.6843676.

16. Jilkov, V.P., Li, X.R. and DelBalzo, D. (2007), Best combination of multiple objectives for UAV search \& track path optimization, 2007 10th International Conference on Information Fusion, pp. 1-8. https://doi.org/10.1109/ICIF.2007.4408202.

17. Pitre, R.R., Li, X.R. and Delbalzo, R. (2012), UAV route planning for joint search and track missions - An information-value approach, IEEE Transactions on Aerospace and Electronic Systems, Vol. 48, Issue 3, pp. $2551-2565$. https://doi.org/10.1109/TAES.2012.6237608.

18. Ha, I.K. and Cho, Y.Z. (2018), A probabilistic target search algorithm based on hierarchical collaboration for improving rapidity of drones, Sensors, No. 18(8), pp. 2535. https://doi.org/10.3390/s18082535.

19. Huang, Q., Yao, J., Li, Q. and Zhu, Y. (2016), Cooperative searching strategy for multiple unmanned aerial vehicles based on modified probability map, Theory, Methodology, Tools and Applications for Modeling and Simulation of Complex Systems, pp. 279-287. https://doi.org/10.1007/978-981-10-2666-9_27.

20. Horodnov, V.P., Smyrnov, E.B., Trystan, A.V. and Chernavyna, O.E. (2012), "Vybor pokazateley i kriteriyev dlya otsenki effektivnosti vedeniya vozdushnoy razvedki po vyyavleniyu NVF" [Selection criteria and indicators for evaluation of the effectiveness aerial reconnaissance the identification of illegal armed groups], Science and Technology of the Air Force of Ukraine, No. 1(7), pp. 58-62.

21. Tymochko, O., Timochko, O., Trystan, A., Matiushchenko, O. and Berezhnyi, A. (2020), Method of Automated Flight Route Planning for Unmanned Aerial Vehicles to Search for Stationary Objects, 2020 IEEE 11th International Conference on $\begin{array}{llllll}\text { Dependable Systems, } & \text { Services } \quad \text { and } & \text { Technologies } & \text { (DESSERT), } & \text { pp. } & \end{array}$ https://doi.org/10.1109/DESSERT50317.2020.9125084.

22. Tymochko, O., Trystan, A., Berezhnyi, A., Sotnikov, O., Matiushchenko, O. and Kryzhanivskyi, I. (2020), Vehicles while Monitoring Behavior of Dynamic Objects in a Forest-Steppe Area, International Journal of Emerging Trends in Engineering Research, Vol. 8, No. 7, pp. 3208-3215. https://doi.org/10.30534/ijeter/2020/54872020.

23. Chernavina, O.Ye. (2010), "Metodika obosnovaniya ratsional'nogo resheniya na vedeniye vozdushnoy razvedki nezakonnykh vooruzhennykh formirovaniy v lesistoy mestnosti” [Methodology for substantiating a rational decision to conduct air reconnaissance of illegal armed formations in a forest area], Science and Technology of the Air Force of Ukraine, No. 2(4), pp. 49-54.

24. Smyrnov, E.B., Trystan, A.V. and Chernavyna, O.Ye. (2011), "Kriterial'nyye otsenki vybora ratsional'nykh marshrutov vedeniya vozdushnoy razvedki dlya obnaruzheniya podvizhnykh ob"yektov v gorno-lesistoy mestnosti” [Criteria for the Choice of Rational Routes of Air Reconnaissance to Detect Moving Objects in Mountainous and Forested Terrain], Information Processing Systems, No. 5(95), pp. 102-107.

25. Smyrnov, E.B., Trystan, A.V. and Chernavyna, O.Ye. (2011), “Opisaniye modeli dvizheniya grupp nezakonnykh vooruzhennykh formirovaniy pri prinyatii resheniya na vedeniye vozdushnoy razvedki v gorno-lesistoy mestnosti” [Description of the model of movement of groups of illegal armed formations when making a decision to conduct aerial reconnaissance in a mountainous forest area], Control, Navigation and Communication Systems, No. 3(19). pp. 241-245.

\section{Список літератури}

1. Бережний А.О. Методи та інформаційна технологія автоматизованого планування маршрутів польотів безпілотних літальних апаратів для підвищення ефективності пошуку об'єктів: автореферат дис. ... канд. техн. наук: 05.13.06 / Бережний Андрій Олександрович. - Черкаси, 2020. - 20 с.

2. Kamate S. Application of object detection and tracking techniques for unmanned aerial vehicles / S. Kamate, N. Yilmazer // Procedia Computer Science. - 2015. - Vol. 61. - P. 436-441. https://doi.org/10.1016/j.procs.2015.09.183.

3. Крылов И.Г. Разработка информационной технологии организации согласованных действий группы беспилотных летательных аппаратов при поиске мобильных наземных объектов: дисс. ... канд. техн. наук: 05.13.01 / Крылов И.Г. - М.: МАИ, 2012. - 143 c.

4. Saif A.F.M. Moving object detection using dynamic motion modelling from UAV aerial images / A.F. M. Saif, A.S. Prabuwono, Z.R. Mahayuddin // The Scientific World Journal. - 2014. - P. 12. http://dx.doi.org/10.1155/2014/890619

5. Coşkun M. Implementation of tracking of a moving object based on camshift approach with a UAV / M. Coşkun, S. Ünal // Procedia Technology. - 2016. - No. 22. - P. 556-561. https://doi.org/10.1016/j.protcy.2016.01.116.

6. Plastiras G. Efficient convnet-based object detection for unmanned aerial vehicles by selective tile processing / G. Plastiras, C. Kyrkou, T. Theocharides // Proceedings of the 12th International Conference on Distributed Smart Cameras. - Sept. 2018. - No. 3-4. - P. 1-6. https://doi.org/10.1145/3243394.3243692. 
7. Waharte S. Probabilistic search with agile UAVs / S. Waharte, A. Symington, N. Trigoni // 2010 IEEE International Conference on Robotics and Automation. - 2010. - P. 2840-2845.

8. Delle Fave F.M. Decentralised Coordination of Unmanned Aerial Vehicles for Target Search using the Max-Sum Algorithm / F. M. Delle Fave, Z. Xu, A. Rogers, N.R. Jennings // AAMAS 2010 Workshop on Agents in Real Time and Environment. - Canada, 10-14 May 2010. - P. 35-44.

9. Balancing search and target response in cooperative unmanned aerial vehicle (UAV) teams / Y. Jin, Y. Liao, A.A. Minai, M.M. Polycarpou // IEEE Transactions on Systems, Man, and Cybernetics, Part B (Cybernetics). - Jun. 2006. - Vol. 36, No. 3. P. 571-587.

10. Lee M.H. Detection and tracking of multiple moving vehicles with a UAV / M.H. Lee, S. Yeom // International Journal of Fuzzy Logic and Intelligent Systems. Sept. 2018. - Vol. 18, No. 3. - P. 182-189. http://doi.org/10.5391/IJFIS.2018.18.3.182.

11. Multi-agent Time-based Decision-making for the Search and Action Problem / T. Miki, M. Popović, A. Gawel, G. Hitz, R. Siegwart // 2018 IEEE International Conference on Robotics and Automation (ICRA) . - 2018. - P. 2365-2372.

12. Coutinho W.P. The unmanned aerial vehicle routing and trajectory optimisation problem, a taxonomic review / W.P. Coutinho, M. Battarra, J. Fliege // Computers \& Industrial Engineering. - 2018. - No. 120. - P. 116-128.

13. Норсеев С.А. Алгоритмы предполетного квазиоптимального определения маршрутов группы беспилотных летательных аппаратов: дисс. ... канд. техн. наук: 05.13.01 / Норсеев С.А. - Ковров, 2016. - 182 с.

14. George J. Search strategies for multiple UAV search and destroy missions / J. George, P.B. Sujit, J.B. Sousa // Journal of Intelligent \& Robotic Systems. - Jan. 2011. - Vol. 61, Issue 1-4. - P. 355-367.

15. Unmanned aerial vehicles routing problem / D. Teichmann, M. Dorda, J. Vítek, V. Smrž, V. Michalík // Proceedings of the 2014 15th International Carpathian Control Conference (ICCC). - 28-30 May 2014. - P. 602-607. https://doi.org/10.1109/CarpathianCC.2014.6843676.

16. Jilkov V.P. Best combination of multiple objectives for UAV search \& track path optimization / V.P. Jilkov, X.R. Li, D. DelBalzo // 2007 10th International Conference on Information Fusion. - 2007. - P. 1-8. https://doi.org/10.1109/ICIF.2007.4408202.

17. Pitre R.R. UAV route planning for joint search and track missions - An information-value approach / R.R. Pitre, X.R. Li, R. Delbalzo // IEEE Transactions on Aerospace and Electronic Systems. - July 2012. - Vol. 48, Issue 3. - P. $2551-2565$. https://doi.org/10.1109/TAES.2012.6237608.

18. Ha I.K. A probabilistic target search algorithm based on hierarchical collaboration for improving rapidity of drones / I.K. Ha, Y.Z. Cho // Sensors. - Aug. 2018. - No. 18(8). - P. 2535. https://doi.org/10.3390/s18082535.

19. Cooperative searching strategy for multiple unmanned aerial vehicles based on modified probability map / Q. Huang, J. Yao, Q. Li, Y. Zhu // Theory, Methodology, Tools and Applications for Modeling and Simulation of Complex Systems. 2016. - P. 279-287. https://doi.org/10.1007/978-981-10-2666-9_27.

20. Выбор показателей и критериев для оценки эффективности ведения воздушной разведки по выявлению НВФ / В.П. Городнов, Е.Б. Смирнов, А.В. Тристан, О.Е. Чернавина // Наука і техніка Повітряних Сил. - Х.: ХУПС, 2012. № 1(7). - C. 58-62.

21. Method of Automated Flight Route Planning for Unmanned Aerial Vehicles to Search for Stationary Objects / O. Tymochko, O. Timochko, A. Trystan, O. Matiushchenko, A. Berezhnyi // 2020 IEEE 11th International Conference on Dependable Systems, Services and Technologies (DESSERT). - Kyiv, Ukraine, May 2020. - P. 242-246. https://doi.org/10.1109/DESSERT50317.2020.9125084.

22. Vehicles while Monitoring Behavior of Dynamic Objects in a Forest-Steppe Area / O. Tymochko, A. Trystan, A. Berezhnyi, O. Sotnikov, O. Matiushchenko, I. Kryzhanivskyi // International Journal of Emerging Trends in Engineering Research. - 2020. - Vol. 8, No. 7. - P. 3208-3215. https://doi.org/10.30534/ijeter/2020/54872020.

23. Чернавина О.Е. Методика обоснования рационального решения на ведение воздушной разведки незаконных вооруженных формирований в лесистой местности / О.Е. Чернавина // Наука і техніка Повітряних Сил Збройних Сил України. - 2010. - № 2(4). - С. 49-54.

24. Смирнов Е.Б. Критериальные оценки выбора рациональных маршрутов ведения воздушной разведки для обнаружения подвижных объектов в горно-лесистой местности / Е.Б. Смирнов, А.В. Тристан, О.Е. Чернавина // Системи обробки інформації. - 2011. - № 5(95). - С. 102-107.

25. Смирнов Е.Б. Описание модели движения групп незаконных вооруженных формирований при принятии решения на ведение воздушной разведки в горно-лесистой местности / Е.Б. Смирнов, А.В. Тристан, О.Е. Чернавина // Системи управління, навігації та зв'язку. - 2011. - № 3(19). - С. 241-245.

Received by Editorial Board 22.07.2020 Signed for Printing 18.08.2020

\section{Відомості про авторів:}

\section{Тимочко Олександр Іванович}

доктор технічних наук професор

професор кафедри

Харківського національного

університету Повітряних Сил ім. І. Кожедуба,

Харків, Україна

https://orcid.org/0000-0002-4154-7876

\section{Information about the authors:}

Oleksandr Tymochko

Doctor of Technical Sciences Professor

Professor of Department

of Ivan Kozhedub Kharkiv National

Air Force University,

Kharkiv, Ukraine

https://orcid.org/0000-0002-4154-7876 
Тристан Андрій Вікторович

доктор технічних наук

старший науковий співробітник

начальник наукового відділу

Харківського національного

університету Повітряних Сил ім. І. Кожедуба,

Харків, Україна

https://orcid.org/0000-0003-0494-8125

\section{Чернавіна Оксана Свгеніївна}

кандидат військових наук

доцент кафедри

Національної академії Національної гвардії України,

Харків, Україна

https://orcid.org/0000-0001-9586-2401

\section{Бережний Андрій Олександрович}

перший заступник начальника університету

Харківського національного університету

Повітряних Сил ім. І. Кожедуба,

Харків, Україна

https://orcid.org/0000-0002-7928-2201
Andrii Trystan

Doctor of Technical Sciences

Senior Research

Chief of Scientific Research Department

of Ivan Kozhedub Kharkiv National

Air Force University,

Kharkiv, Ukraine

https://orcid.org/0000-0003-0494-8125

\section{Oksana Chernavina}

Candidate of Military Sciences

Senior Lecturer

of National Academy of the National Guard of Ukraine, Kharkiv, Ukraine

https://orcid.org/0000-0001-9586-2401

Andrii Berezhnyi

First Deputy Chief of the University

of Ivan Kozhedub

Kharkiv National Air Force University,

Kharkiv, Ukraine

https://orcid.org/0000-0002-7928-2201

\title{
МЕТОД ПЛАНУВАННЯ МАРШРУТУ ВЕДЕННЯ ПОВІТРЯНОЇ РОЗВІДКИ ДИНАМІЧНИХ ОБ'ЄКТІВ З ВИКОРИСТАННЯМ БЕЗПІЛОТНИХ ЛІТАЛЬНИХ АПАРАТІВ В ЛІСОСТЕПОВІЙ МІСЦЕВОСТІ
}

\author{
О.І. Тимочко, А.В. Тристан, О.Є. Чернавіна, А.О. Бережний
}

У статті розроблений метод планування маршруту безпілотного літального апарату (БПЛА) з метою пошуку динамічного об'єкту - терористичного угрупування в умовах лісостепової місцевості. Пропонована схема розробки плану ведення повітряної розвідки за допомогою БПЛА включає порядок формування маршруту ведення повітряної розвідки. Відмінною особливістю пропонованої схеми формування плану ведення повітряної розвідки є врахування множини варіантів маршрутів руху динамічного об'єкту та множини маршрутів польоту БПЛА - розвідника. На основі схеми розробки плану ведення повітряної розвідки БПЛА, побудований метод обтрунтування оптимального маршруту ведення повітряної розвідки, запропоновані показники і критерій ефективності ведення пошуку динамічного об'єкту, що дозволяють вибрати з множини варіантів маршрутів один, який найбільш задовольняє меті та завданню пошуку.

В основі методу покладено принцип раџіональності дій двох протилежних сторін, у яких при виборі марирутів руху досягаються протилежні иүілі, щуо дозволяє визначити дві групи показників та критеріїв ефективності: ефективність виконання завдань противником та ефективність виконання завдання БПЛА - розвідником.

Для знаходження оптимального варіанта дій динамічного об'єкту та обтрунтування плану ведення повітряної розвідки за допомогою БПЛА і прийняття рішення на пошук використано алгоритми, які побудовані на відомих математичних методах теорії дослідження операчій і теорії графів та передбачають аналіз плану дій динамічного об'єкту при досягненні ним об'єктів впливу. В результаті експерименту отримана чисельна очінка показника ефективності ведення пошуку для вибору одного рачіонального маршруту польоту пошукових безпілотних літальних апаратів в умовах невизначеності дій терористичного угрупування.

Ключові слова: безпілотний літальний апарат, планування маршруту, пошук динамічних об'єктів, терористичне угрупування, пошукова операція, лісостепова місцевість.

\section{МЕТОД ПЛАНИРОВАНИЯ МАРШРУТА ВЕДЕНИЯ ВОЗДУШНОЙ РАЗВЕДКИ ДИНАМИЧЕСКИХ ОБЪЕКТОВ С ИСПОЛЬЗОВАНИЕМ БЕСПИЛОТНЫХ ЛЕТАТЕЛЬНЫХ АППАРАТОВ В ЛЕСОСТЕПНОЙ МЕСТНОСТИ}

А.И. Тимочко, А.В. Тристан, О.Е. Чернавина, А.А. Бережной

В статье разработан метод планирования маршрута беспилотного летательного аппарата с целью поиска динамического объекта - террористической группировки в условиях лесостепной местности. Рассмотрен проиесс планирования маршрута беспилотного летательного аппарата с учетом возможных вариантов перемещения террористической группировки в лесостепной местности. Предложены показатели и критерий эффективности ведения поиска с участием беспилотного летательного аппарата, позволяющие выбрать из множества вариантов маршрутов один, который наиболее удовлетворяет целям и задачам поиска. В результате эксперимента получена численная оценка показателя эффективности ведения поиска для выбора одного рационального маршрута полета поисковых беспилотных летательных аппаратов в условиях неопределенности действий террористической группировки.

Ключевые слова: беспилотный летательный аппарат, планирование марирута, поиск динамических объектов, террористическая группировка, поисковая операция, лесостепная местность. 